\title{
先行車に追従する自動運転車両の目標軌跡生成と制御手法の提案
}

\author{
西崎 浩平 ${ }^{* 1}$ ，毛利 宏 ${ }^{* 2}$
}

\section{Investigation on the target trajectory generation of the preceding vehicle following control}

\author{
Kohei NISHIZAKI ${ }^{* 1}$ and Hiroshi MOURI ${ }^{* 2}$ \\ ${ }^{*} 1,{ }^{* 2}$ Tokyo University of Agriculture and Technology \\ 2-24-16 Naka-cho, Koganei-shi, Tokyo 183-0057, Japan
}

Received: 26 March 2017; Revised: 21 May 2017; Accepted: 11 July 2017

\begin{abstract}
Preceding vehicle following control system has been investigated widely. In many previous studies, the vehicular gap is assumed to be short, so the following vehicle can travel stably only by using heading angle toward preceding vehicle. However, the vehicle gap sometimes becomes longer at the complex surroundings such as intersection, so there is a problem that the following vehicle tends to travel along a shortcut path. Therefore, the preceding vehicle trajectory needs to be recognized correctly, but it is impossible because the system can use only current preceding vehicle position. We proposed the algorithm of the preceding vehicle trajectory generation. In the algorithm, the relative preceding vehicle position that is recognized at each period is hold. And each position is converted into the coordinate fixed to the present ego-vehicle. After that point sequence is generated by each position data. By using least squares method, the preceding vehicle point sequence is approximated by a curve line as the preceding vehicle trajectory. By using the trajectory as the target path for course following control, it becomes possible to follow the preceding vehicle regardless of the vehicular gap. Moreover, the validity of the proposed method is confirmed by the experiment conducted with an actual vehicle.
\end{abstract}

Key words : Automatic driving system, Vehicle dynamics, Proceeding vehicle following control, Target trajectory generation, Steering control

\section{1. 緒言}

我が国は都市に産業，人口が集中しているため，都市部では公共交通機関が発達しているのに対し，地方のよ うな公共交通が十分でない地域では，移動手段として自動車に依存している。しかし，超高齢社会となり，十分 な運転能力を持たないドライバの増加，自動車交通事故の死者における高齢者の割合増加が問題視されており， 移動制約者は増加の一途をたどる．政府はこういった移動制約者の生活の質を向上させるために 2020 年を目標 とし「ラストワンマイル自動運転」というコンセプトを掲げている．これは，希望する方面に向かう先導車に自 動追従し，目的地が近づくと自動で離脱し目的地まで自動走行するというものである. このようなコンセプト実 現のため, 先行車追従システムに注目が集められている.

これまで先行車追従制御の研究は数多く提案されている（深町他，2013）（大前他，2001）。NEDO は車線追従 制御を用いて大型トラックによる時速 80km の自動隊列走行を成功させている(深尾, 杉町, 2014). また, SARTRE のように同様のプロジェクトが各国で進行しており，実用化は近い（経産省自動走行ビジネス検討会，2016）。し かし，高速道路では車線認識が容易にできるのに対し，市街地のような，交差点や白線認識のできない道路のあ る複雑な環境下においては，白線認識に頼らない手法が必要となる（大前，藤岡，2005）.

白線認識を必要としない先行車追従では, 先行車情報をもとに操舵を制御する手法が提案されている.例えば, 自車に対する先行車の相対角度を目標として直接操舵角を求め, $0.4 \mathrm{~m}$ の車間距離で高密度な隊列走行が実現され

\footnotetext{
No.17-00137 [DOI: 10.1299/transjsme.17-00137], J-STAGE Advance Publication date : 26 July, 2017

*1 東京農工大学（†183-0057 東京都小金井市中町 2-24-16）

$*_{2}$ 正員, 東京農工大学

E-mail of corresponding author: s153222x@st.go.tuat.ac.jp
} 
ている(大前他，2008). また，地点追従手法を用いて，車車間通信によって取得した自車に対する先行車の位置と 方位から自車の操舵角を決定する手法が提案され， $2.5 \mathrm{~m}$ という短い車間距離の先行車追従が行われている(津川 他，1990)，（菅沼他，1999）.

これまで提案されてきた手法では，短い車間距離を前提としており，車間距離が変化した場合の先行車追従は 考慮されていない，実際，市街地での先行車追従制御を行う場合，車間距離は周りの状況に合わせて变化しうる ため，車間距離に関わらず先行車と同様の軌跡の走行が求められる.

しかし, 従来提案されている手法では, 現在の先行車との相対的な位置関係しか認識できず, 先行車の通った 軌跡が残らないため，車間距離が長くなると，先行車同様の軌跡を走行することが困難であることが明らかにな っている（近藤，1967）（Yoshimoto，1969），（古性他，2014）。車間距離に関らず先行車同様の軌跡を走行するた めには，現在の先行車情報を目標点とするのでなく，先行車が走行した過去の軌跡を取得し，その軌跡を目標軌 跡とするシステムが必要となる.

本研究では，車間距離に関わらず，先行車と同様の軌跡を走行可能なシステムを実現するための目標軌跡を生 成する手法を提案し, また, 生成した軌跡の追従手法の検討も行う.さらに, 本手法を使用し先行車追従制御を 実車実験にて行い，有効性を検証する.

\section{2. 先行車軌跡生成アルゴリズム}

\section{$2 \cdot 1$ 従来手法}

はじめに，短い車間距離が前提とされている従来手法において車間距離が車両軌跡にどのような影響及ぼすか を確認する.

図 1 のように自車進行方向に対し先行車位置の方向がな寸角 $\theta$ にゲインをかけ，式(1)のように操舵角 $\delta$ を決定 する.

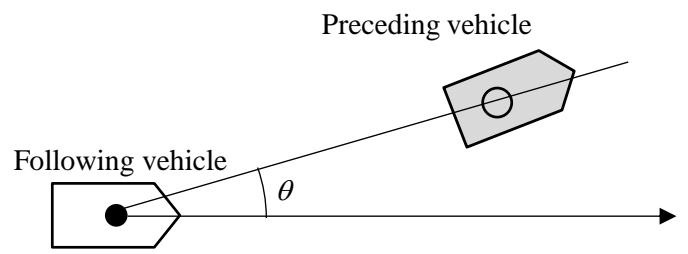

Fig.1 Conventional method.

The figure shows Conventional method that the steering wheel angle is calculated by using heading angle toward preceding vehicle.

$$
\delta=K \theta
$$

ここで，ゲイン $K$ は提案されている手法によって動特性を持つものや変数である場合もあるが，本報では定数 とする.

本手法を使用し，曲率 $10 \mathrm{~m}$ の右折走行時の先行車追従制御のシミュレーションを行うと図 2 のようになる. な お，車間距離は $2 ， 5 ， 10 ， 15 \mathrm{~m}$ ，車速は $10 \mathrm{~km} / \mathrm{h}$ としている.

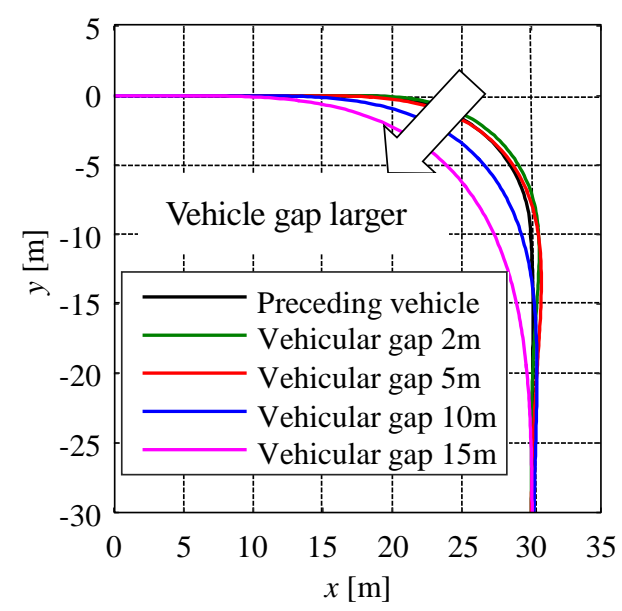

Fig.2 Vehicle trajectory in right turn. 
When the vehicle gap becomes large, the following vehicle travels along a shortcut path.

車間距離が長くなるに従い，先行車軌跡に対しショートカットした挙動を示すことがわかる. このような挙動 は右折に限らず様々な場面において影響を及ぼすと考えられる.

このような問題を解決するため，先行車追従制御時に目標軌跡となる先行車軌跡を生成する手法を提案する.

\section{$2 \cdot 2$ 提案手法}

先行車軌跡生成を含んだ先行車追従制御全体の流れを図 3 に示し, 概要図を図 4 に示す.

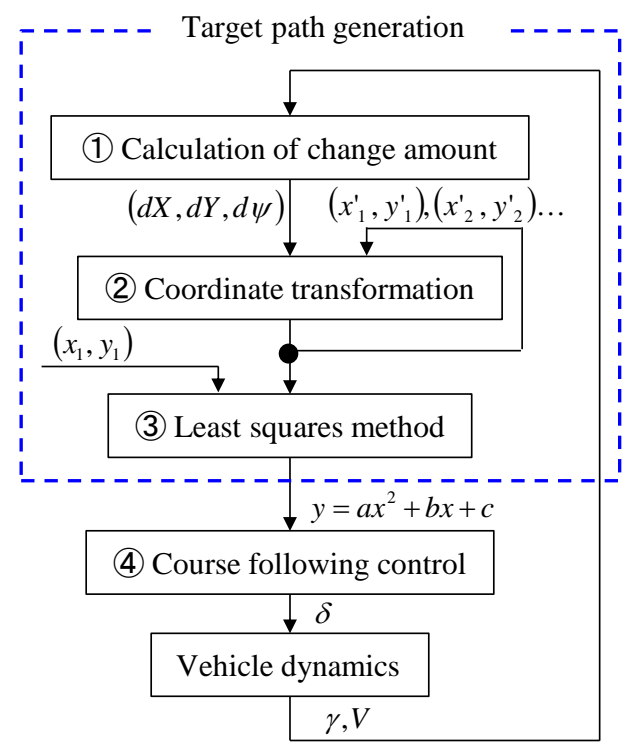

Fig.3 Flow chart of proceeding vehicle following control.

This figure shows how the controller is organized using flow chart. The portion surrounded by a blue dashed line is the target path generation part.

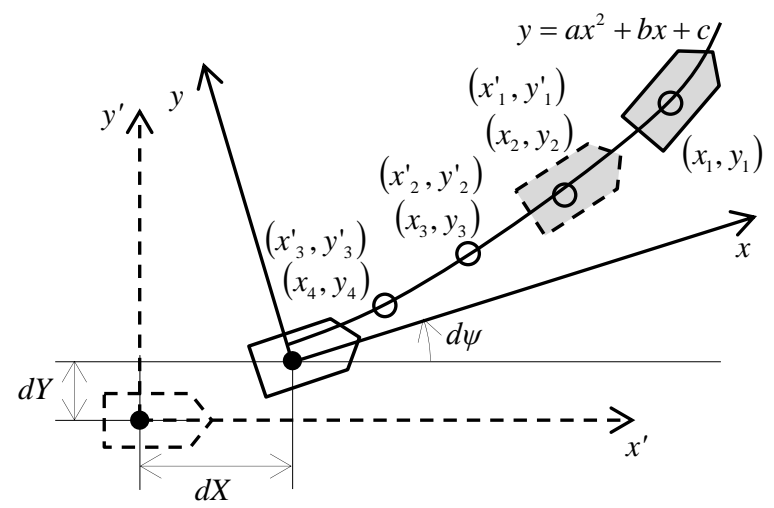

Fig.4 Overview of target trajectory generation.

The coordinates move with the own vehicle. Although the trajectory of the preceding vehicle exists on the absolute coordinate, each point of the preceding vehicle is converted into the value of the coordinate of the own vehicle every moment.

図 3 の青点線で囲まれた部分が軌跡生成を示しており，(1)自車変化量算出，(2)過去の先行車位置の座標変換， (3)最小二乗法による先行車軌跡生成という三つの工程より成り立つ. 
図 4 に示すように，自車は先行車の過去座標 $\left(x^{\prime}{ }_{1}, y^{\prime}{ }_{1}\right),\left(x_{2}^{\prime}, y_{2}^{\prime}\right),\left(x_{3}^{\prime}, y_{3}^{\prime}\right)$...を常に保持している. 自車センサよ

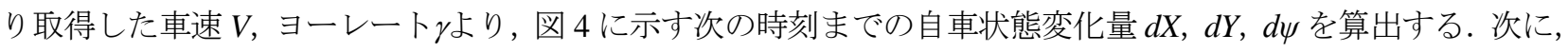
算出された自車状態変化量より, 先行車の過去座標を自車固定座標系へと変換し, 先行車過去座標 $\left(x_{2}, y_{2}\right),\left(x_{3}, y_{3}\right)$, $\left(x_{4}, y_{4}\right)$...を得る. そして, センサより取得した現在の先行車座標 $\left(x_{1}, y_{1}\right)$ と先ほど得られた過去の先行車座標に対し 最小二乗法を使用して二次曲線に近似する．以下にそれぞれの工程の詳細を示す.

(1) 自車変化量算出

図 5 にサンプリング時間 $T_{s}$ 秒間の車両移動を示す. 自車の $x$ 座標変化量を $d X, y$ 座標変化量を $d Y$, ヨ一角変 化量 (=旋回角度) を $d \psi$ とし, また，相対距離を $D$ とすると， $d X, d Y$ は式(2)で示される.

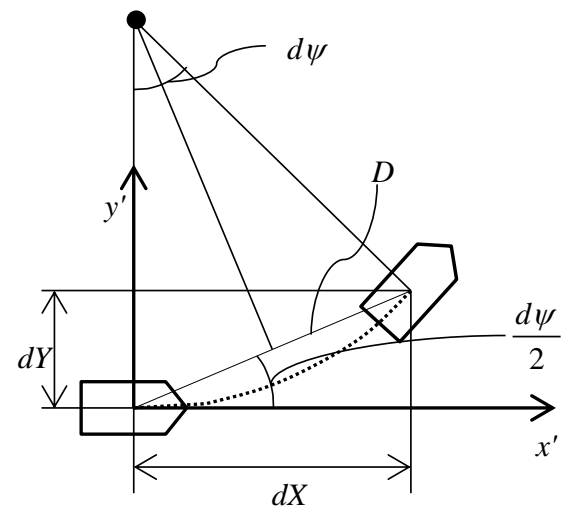

Fig.5 Vehicle movement in sampling time $T_{s .}$

Vehicle movement is calculated by using Arc approximation.

$$
\left\{\begin{array}{l}
d X=D \cos \left(\frac{d \psi}{2}\right) \\
d Y=D \sin \left(\frac{d \psi}{2}\right)
\end{array}\right.
$$

自車のヨーレートを $\gamma$ ，車速を $V$ とすると， $D, d \psi$ は式(3)で示される.

$$
\left\{\begin{aligned}
D & =V T_{s} \\
d \psi & =\gamma T_{s}
\end{aligned}\right.
$$

したがって, 式(2), (3)より, 式(4)に示すように，ヨーレートと車速より自車変化量を計算することができ る.

$$
\left\{\begin{array}{l}
d X=V T_{s} \cos \left(\frac{\gamma T_{s}}{2}\right) \\
d Y=V T_{s} \sin \left(\frac{\gamma T_{s}}{2}\right) \\
d \psi=\gamma T
\end{array}\right.
$$

(2) 過去の先行車位置の座標変換

(1)で得られた自車変化量 $d X, d Y, d \psi$ と, センサから得られる現在の先行車座標 $\left(x_{\text {sensor }}, y_{\text {sensor }}\right)$ を用いて, 式(5), (6)に示すように自車固定座標系へと変換し，先行車座標 $\left(x_{1}, y_{1}\right),\left(x_{2}, y_{2}\right),\left(x_{3}, y_{3}\right),\left(x_{4}, y_{4}\right) \ldots$ を得る. $k=1$ のとき 


$$
\begin{gathered}
\left\{\begin{array}{l}
x_{k}=x_{\text {sensor }} \\
y_{k}=y_{\text {sensor }}
\end{array}\right. \\
k \geqq 2 \text { のとき, } \\
\left\{\begin{array}{l}
x_{k}=\left(x^{\prime}{ }_{k-1}-d X\right) \cos (d \psi)+\left(y_{k-1}^{\prime}-d Y\right) \sin (d \psi) \\
y_{k}=-\left(x^{\prime}{ }_{k-1}-d X\right) \sin (d \psi)+\left(y^{\prime}{ }_{k-1}-d Y\right) \cos (d \psi)
\end{array}\right.
\end{gathered}
$$

\section{(3) 最小二乗法による先行車軌跡生成}

得られた先行車座標 $\left(x_{1}, y_{1}\right) ，\left(x_{2}, y_{2}\right) ，\left(x_{3}, y_{3}\right) ，\left(x_{4}, y_{4}\right) \ldots$ に対し最小二乗法を使用し先行車軌跡を生成する. なお, 先行車軌跡は陽関数で扱いやすい二次曲線として近似する. しかし, 先行車座標を全点使用寸ると図 6 の(a)のよ うに二次曲線では表しきれない場合があるため, 使用する先行車座標を図 6(b)のように制御に使用する範囲内の 先行車座標を使用する.

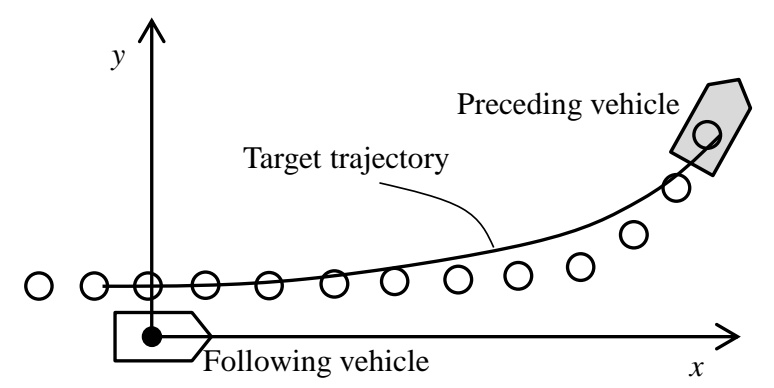

(a) All points are used

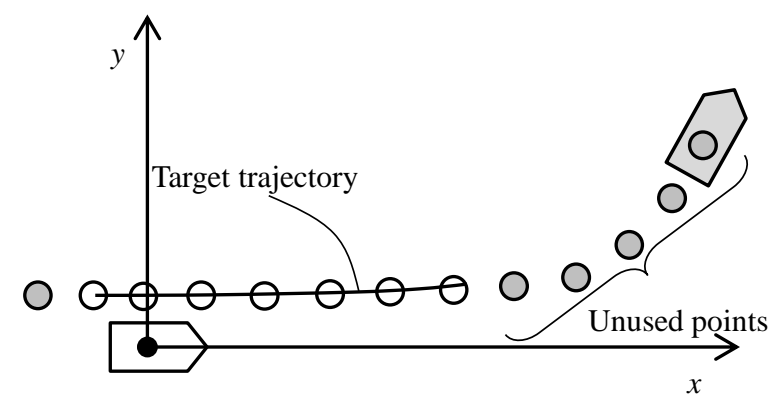

(b) A part of points are used

Fig.6 Used preceding vehicle position.

The generated target trajectory by using all preceding vehicle position data (a) is more exact than one by using a part of preceding vehicle position data (b). However, new candidate points of preceding vehicle are far from the position of the present own vehicle and they assume to have relatively large error, so the nearer points are employed to make target trajectory.

最小二乗法で使用する点を $\left(x_{m}, y_{m}\right),\left(x_{m+1}, y_{m+1}\right) \ldots\left(x_{n}, y_{n}\right)$ とすると, 二次曲線の係数 $a, b, c$ は以下の正規方程式 より得ることができる.

$$
\left(\begin{array}{lll}
\sum_{k=m}^{n} x_{k}^{4} & \sum_{k=m}^{n} x_{k}^{3} & \sum_{k=m}^{n} x_{k}^{2} \\
\sum_{k=m}^{n} x_{k}^{3} & \sum_{k=m}^{n} x_{k}^{2} & \sum_{k=m}^{n} x_{k} \\
\sum_{k=m}^{n} x_{k}^{2} & \sum_{k=m}^{n} x_{k} & \sum_{k=m}^{n} 1
\end{array}\right)\left(\begin{array}{l}
a \\
b \\
c
\end{array}\right)=\left(\begin{array}{l}
\sum_{k=m}^{n} x_{k}^{2} y_{k} \\
\sum_{k=m}^{n} x_{k} y_{k} \\
\sum_{k=m}^{n} y_{k}
\end{array}\right)
$$


得られた軌跡を目標軌跡とし目標軌跡追従制御を行うことで，先行車と同様の軌跡を走行する.

本手法では自車センサによる誤差が座標変換時に生じるが，毎時刻先行車座標が真值として得られるため，制 御に使用する範囲の久を使用する限り, 誤差が積分され蓄積されることはない. また, 最小二乗法を利用するこ とで，点列のばらつきを抑制し，なおかつ連続的な目標軌跡を推定できる.

\section{$2 \cdot 3$ 目標軌跡追従システム}

$2 \cdot 2$ 節で述べた手法を用いて生成した先行車軌跡を目標軌跡として, 先行車追従制御シミュレーション, 実車 実験を行う。そこで, 図 3 の(4)で述べた目標軌跡追従手法について述べる.

目標軌跡追従手法として二点前方注視モデル(古性他, 2014)を使用する. この手法では, 自車前方に二点の前方 注視点を置き，それぞれの前方注視点における目標軌跡との偏差を用いて自車の目標ヨーレートを算出する. そ して, 目標ヨーレートを実現するように操舵することで目標軌跡を追従できる. 本手法は従来不可能であった目 標軌跡追従動特性（固有振動数, 減衰比）を任意に決めることができるため, 収束性に関わる減衰比の向上を可 能とする.ここで，図 7 に二点前方注視モデルの概要を示す.

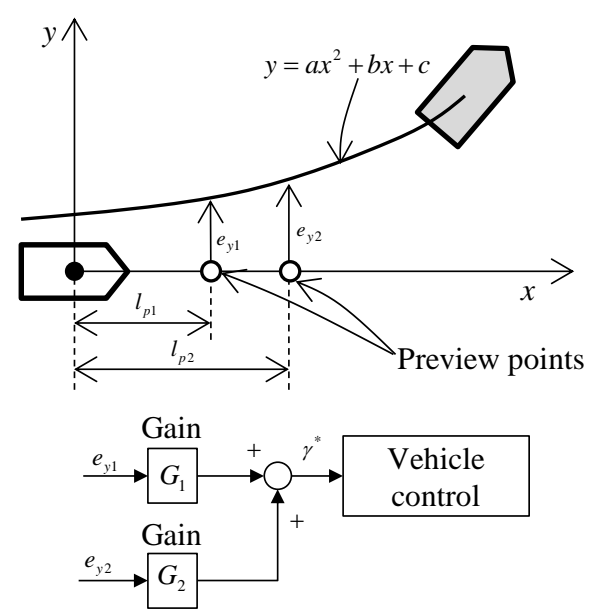

Fig.7 Overview of dual preview points system.

The target yaw rate is calculated using the deviation at dual preview points.

図 7 に示寸前方注視点における偏差 $e_{y 1}, e_{y 2}$ は 2.2 節で生成される二次曲線の式 $\left(y=a x^{2}+b x+c\right)$ を用いて式 $(8) の$ ように表すことができる.

$$
\begin{aligned}
& e_{y 1}=a l_{p 1}^{2}+b l_{p 1}+c \\
& e_{y 2}=a l_{p 2}^{2}+b l_{p 2}+c
\end{aligned}
$$

ただし， $l_{p 1}, l_{p 2}$ は前方注視距離とする. 算出した偏差 $e_{y 1}, e_{y 2}$ にそれぞれ異なるゲイン $G_{1}, G_{2}$ をかけ，足し合

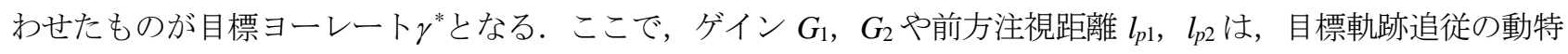
性である固有振動数と減衰比を任意に決めることにより式(9), (10)のように得られる.

$$
\begin{aligned}
& l_{p 1}=\frac{\zeta(1+k) \pm \sqrt{\zeta^{2}(1+k)^{2}-2 k}}{k \omega_{n}} V \\
& l_{p 2}=\frac{\zeta(1+k) \pm \sqrt{\zeta^{2}(1+k)^{2}-2 k}}{\omega_{n}} V
\end{aligned}
$$




$$
\begin{aligned}
G_{1}= & \frac{\omega_{n}^{2}\left(\zeta^{2}(1+k)-k \mp \zeta \sqrt{\zeta^{2}(1+k)^{2}-2 k}\right)}{V(1-k)} \\
G_{2}= & \frac{\omega_{n}^{2}\left(1-\zeta^{2}(1+k) \pm \zeta \sqrt{\zeta^{2}(1+k)^{2}-2 k}\right)}{V(1-k)}
\end{aligned}
$$

\section{$2 \cdot 4$ 机上検討}

$2 \cdot 2$ 節で示した先行車軌跡生成手法, $2 \cdot 3$ 節で示した目標軌跡追従手法を用いて，先行車追従シミュレーショ ンを行う.シミュレーションに用いた車両モデルは等価二輪モデル(安部，1992)を使用する. 先行車座標はサンプ リング時間 $0.1 \mathrm{~s}$ で得られるものとし，先行車軌跡の更新も $0.1 \mathrm{~s}$ ごとに行う。また，自車の車速，ヨーレートには それぞれ最大 $0.1 \mathrm{~m} / \mathrm{s}, 1 \mathrm{deg} / \mathrm{s}$ ほどのランダムノイズを入力した. 図 8 に車両軌跡, 図 9 に操舵角の時系列データ を示す. 図 10 には先行車と自車の車両軌跡の誤差を示す. なお, 先行車軌跡に対する自車位置の最短距離を誤差 として計算している.

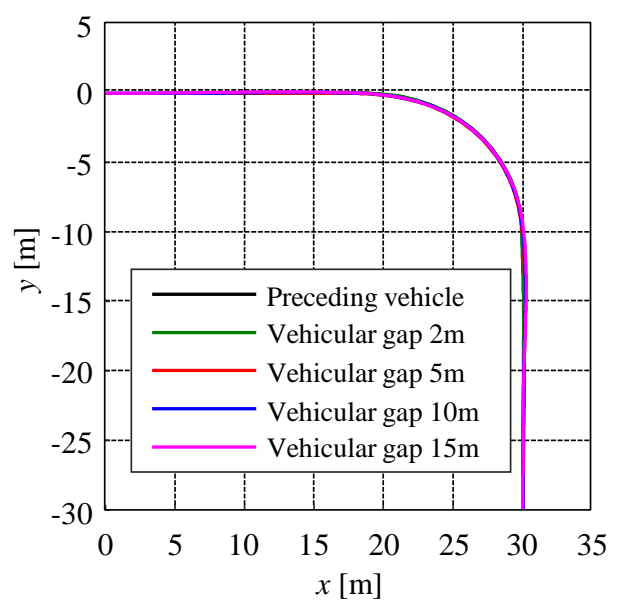

Fig.8 Vehicle trajectory of the simulation.

By using the proposed method, it can be seen that the own vehicle can run on the locus of the preceding vehicle regardless of the inter-vehicle distance.

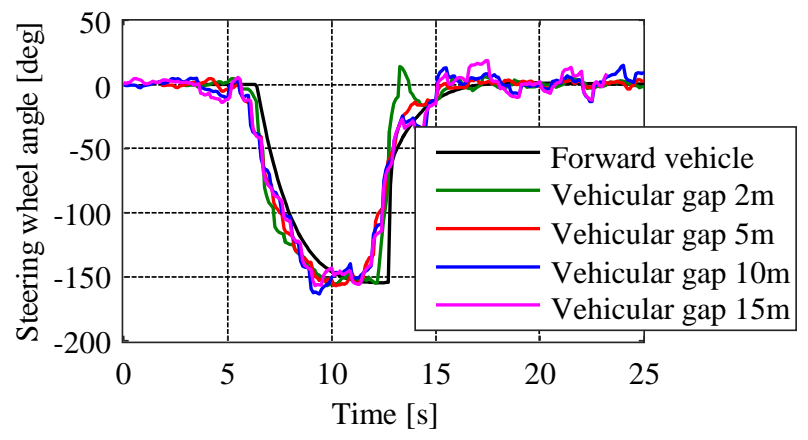

Fig.9 Steering wheel angle of the simulation.

As shown in Fig. 9, the steering timing of the following vehicle is earlier than one of the preceding vehicle, but the ego-vehicle follows the preceding vehicle regardless of the vehicular gap. 


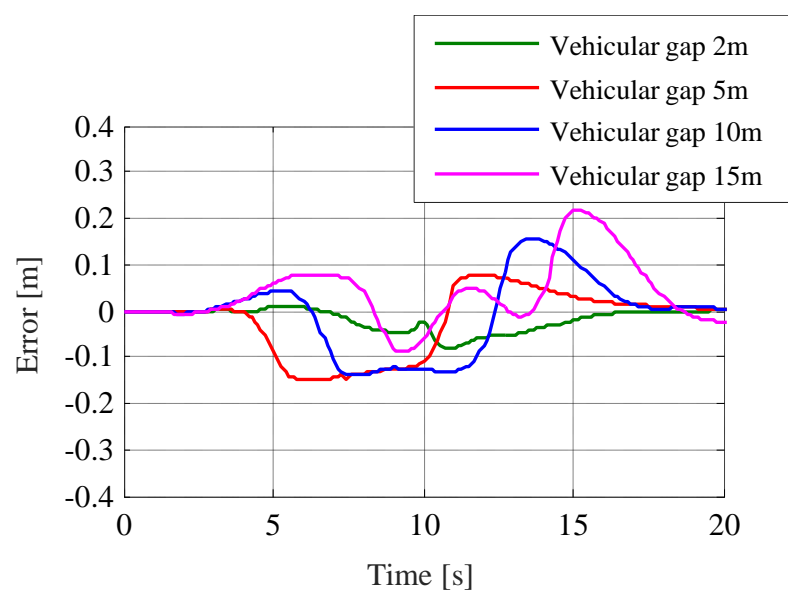

Fig.10 Deviation between predictive vehicle trajectory and following vehicle trajectory in the simulation.

The deviation between predictive vehicle trajectory and following vehicle trajectory is about $0.2 \mathrm{~m}$ at most.

図 9 のように, 先行車位置への到達時間分先行車の操舵角をずらすと，操舵の開始時間や操舵角最大時の時間 が先行車より早いことがわかる，これは，自車が先行車の直線走行経路を追従中に，制御に使用する範囲内で過 去の先行車位置が曲がり始めると，算出される目標軌跡も曲線を描くため，操舵の開始時間や操舵角最大時の時 間が早まると考えられる，操舵は一致しないものの，図８のように車間距離に関わらず，先行車と同様の軌跡を 走行することが確認された. 図 10 より, 自車と先行車の誤差は, 車間距離の増加ととともに誤差は増加している が，約 $0.2 \mathrm{~m}$ に収まっていることがわかる.

本シミュレーションでは，軌跡追従制御に使用する範囲を試行錯誤的に $10 \mathrm{~m}$ とている．使用範囲が $10 \mathrm{~m} よ$ り広い場合，車間距離 $15 \mathrm{~m}$ での誤差が増大する。10m より狭い場合，誤差は変わらないものの，最小二乗法に用 いられる過去の先行車位置のデータ数が少なくなりロバスト性が低くなる.

この条件だけでなく，車速や，コーナ曲率を変更した場合も先行車と同様の軌跡を示し，本手法の有効性を確 認した.

\section{3. 実車実験}

前述した先行車軌跡生成手法を使用し，実車にて先行車追従制御実験を行う。実験車両には一人乗り小型電気 自動車を使用する。 また，安全性を踏まえ先行車は仮想的に走行させ，実験車両にリアルタイムで相対座標情報 を与えるものとする.

曲率 $10 \mathrm{~m}$ の曲線部を右折する仮想先行車に追従して走行する. 車速は仮想先行車，自車ともに $10 \mathrm{~km} / \mathrm{h} と し$, 車間距離は 5, 10, $15 \mathrm{~m}$ とする. 図 11 に実験結果の車両軌跡を, 困 12 に操舵角の時系列データを示す, ただし, 操舵角の時系列データは，車間時間分ずらしている. 図 13 には先行車と自車の車両軌跡の誤差を示す. 図 11 , より, 先行車と同様の走行が確認できる.しかし，図 12 より，車間距離の増加に伴い，最大操舵角が増加してい ることが分かる．この理由は，自車状態量計測や自車変化量算出の誤差の影響と考えられる．過去の先行車位置 は現在の先行車位置から離れるほど誤差が積分される. その結果，生成される目標軌跡の誤差が大きくなり，操 舵角が先行車に対し大きくなったと考えられる. また, 図 13 より, シミュレーションより誤差は大きくなってい るものの，車間距離に関わらず約 $0.4 \mathrm{~m}$ の誤差に収まっていることが分かる.

この結果より，実車においても本手法の有効性を確認することができた. 


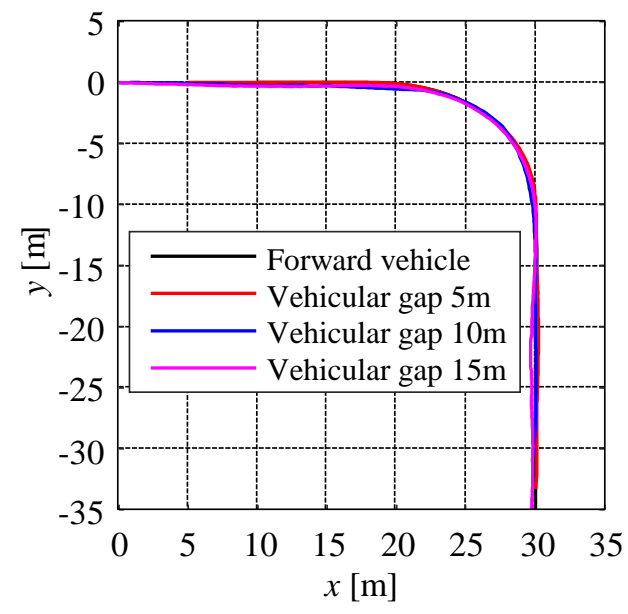

Fig.11 Vehicle trajectory of the experiment result.

According to the figure, the ego-vehicle follows the preceding vehicle regardless of the vehicular gap

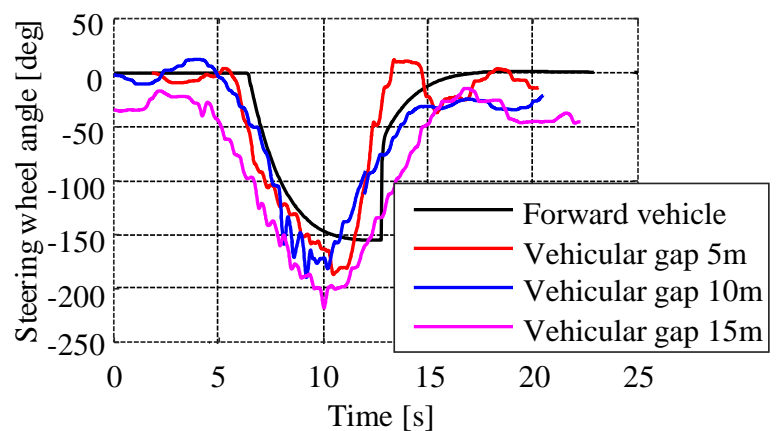

Fig.12 Steering wheel angle of the experiment result

The longer the vehicular gap becomes, the larger the maximum steering wheel angle becomes because measurement error or calculated change amount error of following vehicle.

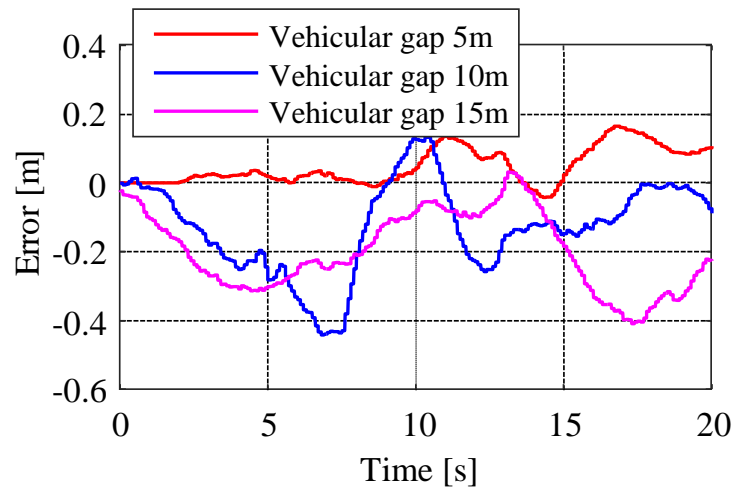

Fig.13 Deviation between predictive vehicle trajectory and following vehicle trajectory.

The deviation between predictive vehicle trajectory and following vehicle trajectory is about $0.4 \mathrm{~m}$ at most.

\section{4. 結 言}

本論文では，先行車追従制御時の目標軌跡を生成する手法として，最小二乗法を用いて先行車軌跡を生成する 手法を提案し，実車を用いて先行車追従制御実験を行い有効性の検証を行った. 
- 自車の状態量と自車に対する現在の先行車座標のみを用いて，先行車の過去の軌跡を自車両固定座標上で表 現し目標軌跡を生成する手法を明らかにした.

・ シミュレーションより, 車速やコーナ曲率, 車間距離に関わらず上記手法の妥当性を確認した.

・実車実験においても車間距離に依らず先行車軌跡を追従し，本手法の有効性が確認された。

\section{文献}

安部正人, 自動車の運動と制御, 山海堂(1992).

梁町弘毅, 渡辺優人, 稲葉敬之, 小菅義夫, 車載レーダにおける NN アソシエーションを適用した先行車両追尾,

電子情報通信学会技術研究報告. SANE，宇宙・航行エレクトロニクス, Vol. 112, No. 391(2013), pp.37-42.

深尾隆則, 杉町敏之, トラックの隊列走行における制御技術, システム/制御/情報：システム制御情報学会誌,

Vol.58, No.5(2014), pp.175-180.

古性裕之, 風間恵介, 孕石泰丈, 毛利宏, 複数の前方注視点を用いた車線追従制御則の提案：定常旋回中の定常

偏差除去と減衰性向上の検討，自動車技術会論文集, Vol. 45, No.2(2014), pp.315-321.

自動走行ビジネス検討会, 自動走行ビジネス検討会 今後の取組方針, 経済産業省, available from

〈http://www.meti.go.jp/press/2015/03/20160323001/20160323001-2.pdf〉, (参照日 2017 年 3 月 10 日).

近藤政市，基礎自動車工学 第 17 章(1967).

大前学, 藤岡健彦, 三宅浩四郎, ITS 環境における DGPS と車車間通信を利用した周囲車両の相対位置計測に関す

る研究, 日本機械学会論文集 C 編, Vol. 67, No. 657(2001), pp. 274-280.

大前学, 藤岡健彦, 大交通容量を実現するためのプラトゥーン走行制御に関する研究, 日本機械学会論文集 C 編,

Vol.67, No.660 (2005), pp.157-164.

大前学, 小木津武樹, 清水浩, 車車間通信を利用した車両内情報の共有による小型電気自動車の高密度隊列走行

に関する研究，自動車技術会論文集, Vol. 39, No. 1(2008), pp.7-13.

菅沼直樹, 松川和史, 絶利谷一, 包躍粧, 藤原直史, 適応地点追従法による移動体の自動追尾走行, 日本機械学会

論文集 C 編, Vol. 65, No. 636(1999), pp.157-162.

津川定之, 村田智, 広瀬武志, 谷田部照男, 車両間通信による自律車両群の走行制御, 計測自動制御学会論文集, Vol.26, No.9 (1990), pp.76-83.

Yoshimoto, K., Simulation of man-automobile systems by the driver's steering model with predictability , Bulletin of JSME,

Vol.12, No.51 (1969) ,pp.495-500.

\section{References}

Abe, M., Automotive vehicle dynamics theory and applications, Sankaido(1992) (in Japanese).

Fukamachi, K., Watanabe, M., Inaba, T. and Kosuge, Y., Vehicle Tracking using nearest neighbor association in automotive radar, The institute of electronics, information and communication engineers technical report, Vol. 112, No. 391(2013), pp.37-42(in Japanese).

Fukao, T. and Sugimachi, T., Control technologies on platooning of trucks, transactions of the institute of systems, control and information engineers, Vol.58, No.5(2014), pp. 175-180(in Japanese).

Furusho, H., Kazama, K., Haramishi, Y. and Mouri, H., Investigation on the driver's steering model employing several preview points : zero steady state error during constant curvature cornering and arbitrary damping characteristics, Transactions of Society of Automotive Engneers of Japan, Vol. 45, No.2(2014), pp315-321(in Japanese).

Jidousoukou Business Kentoukai, Jidousoukou Business Kentoukai Kongo no Torikumihoushin, Ministry of Economy, Trade and Industry, available from < http://www.meti.go.jp/press/2015/03/20160323001/20160323001-2.pdf >, (accessed on 10 March, 2017) (in Japanese).

Kondoh, M., Basic automotive engineering, section 17 (1967) (in Japanese).

Omae, M., Fujioka, T. and Miyake, K., Relative position measurement of neighboring vehicles using DGPS and inter-vehicle communication in ITS environment, Transactions of the Japan Society of Mechanical Engineers, Series C, Vol. 67, No. 657(2001), pp. 274-280 (in Japanese).

Omae, M. and Fujioka, T., Platoon-level control of automatic vehicles' platooning for larger traffic throughput, Transactions of 
the Japan Society of Mechanical Engineers, Series C, Vol.67, No.660 (2005), pp.157-164(in Japanese).

Omae, M., Ogitsu, T. and Shimizu, H., Platooning of electric light vehicles with short inter-vehicle distances by sharing vehicle information, Transactions of Society of Automotive Engneers of Japan, Vol. 39, No. 1(2008), pp. 7-13(in Japanese).

Suganuma, N., Matsukawa, K., Togiya, H., Bao, Y. and Fujiwara, N., Auto-tracking of vehicle by flexible target point following algorithm, Transactions of the Japan Society of Mechanical Engineers, Series C, Vol. 65, No. 636(1999), pp.157-162 (in Japanese).

Tsugawa, S., Murata, S., Hirose, T. and Yatabe, T., Driving control of autonomous vehicles with vehicle-to-vehicle communication, Transactions of the Society of Instrument and Control Engineers, Vol.26, No.9 (1990), pp.76-83(in Japanese).

Yoshimoto, K., Simulation of man-automobile systems by the driver's steering model with predictability, Bulletin of JSME, Vol.12, No.51 (1969) ,pp.495-500. 